\title{
Seasonality of bivalve larvae within a high Arctic fjord
}

\author{
Melissa M. Brandner ${ }^{1,2} \cdot$ Eike Stübner $^{3} \cdot$ Adam J. Reed $^{1} \cdot$ Tove M. Gabrielsen $^{3}$ • \\ Sven Thatje ${ }^{1}$
}

Received: 25 December 2015/Revised: 15 April 2016/Accepted: 18 April 2016/Published online: 6 May 2016

(C) The Author(s) 2016. This article is published with open access at Springerlink.com

\begin{abstract}
The temporal and spatial distribution of larval plankton of high latitudes is poorly understood. The objective of this work is to identify the occurrence and abundance of pelagic bivalve larvae within a high Arctic fjord (Adventfjorden, Svalbard) and to reveal their seasonal dynamics in relation to environmental variables-temperature, salinity and chlorophyll $a$-between December 2011 and January 2013. We applied a combination of DNA barcoding of mitochondrial 16S ribosomal RNA and morphological analysis to identify the bivalve larvae found within the plankton and demonstrate a strong seasonality in the occurrence of bivalve larvae, largely coinciding with periods of primary productivity. Seasonal occurrences of bivalve larval species differ from those known for other populations across species' biogeographic distribution ranges. Serripes groenlandicus, which is of circum-Arctic distribution, demonstrated a later occurrence than Mya truncata or Hiatella arctica, which are of predominantly boreal or cosmopolitan distribution, respectively. $S$. groenlandicus larvae demonstrate the most pronounced response to seasonality, with the shortest presence in the
\end{abstract}

Electronic supplementary material The online version of this article (doi:10.1007/s00300-016-1950-x) contains supplementary material, which is available to authorized users.

Sven Thatje

svth@noc.soton.ac.uk

1 Ocean and Earth Science, University of Southampton, National Oceanography Centre, Southampton, European Way, Southampton SO14 3ZH, UK

2 Present Address: Faculty of Aquaculture and Biosciences, Nord University, PO Box 1490, 8049 Bodø, Norway

3 Department of Arctic Biology, University Centre in Svalbard (UNIS), 9171 Longyearbyen, Norway water column. Establishing latitudinal differences in the occurrence of bivalve larvae enhances our understanding of how reproductive traits of marine invertebrates may respond to climate-driven seasonal shifts in the occurrence of primary productivity.

Keywords Invertebrate reproduction - Bivalves . Meroplankton · Morphology $\cdot$ Diversity $\cdot$ Polar

\section{Introduction}

Strong seasonality shapes high latitude environments, with intra-annual changes in solar irradiance, ice cover, glacial melt water and mixed layer depth, influencing seasonal changes in marine benthic fauna (Wlodarska-Kowalczuk and Pearson 2004). In order to survive within the Arctic marine realm, marine organisms that feed on phytoplankton must be able to respond to short periods of high food availability and prolonged periods of low resources during the polar night (Weslawski et al. 1991). Therefore, it has been suggested that local environmental variables have a direct effect on the timing, occurrence and duration of larval stages of marine benthic invertebrate species (Fetzer and Arntz 2008). Pelagic larval stages are a vector for dispersal and therefore have the capability to alter the abundance and distribution of benthic invertebrate species at a given site (Mileikovsky 1968; Thatje 2012). The role of seasonality on the occurrence and distribution of invertebrate larval plankton in the Arctic, however, remains scarcely known (Kuklinski et al. 2013).

An important Arctic keystone group is the bivalve molluscs, which contribute significantly to benthic biomass in some areas; e.g. in Svalbard molluscs contribute between 10 and $110 \mathrm{~g} \mathrm{ww} \mathrm{m}^{-2}$ to benthic biomass 
annually, in comparison with polychaetes 0-20 $\mathrm{g} \mathrm{ww} \mathrm{m}^{-2}$ and other taxa 0-40 $\mathrm{g} \mathrm{ww} \mathrm{m}^{-2}$ (Pawlowska et al. 2011). Bivalves are also central to the short Arctic food web, by providing a resource to top trophic species, such as walrus, seals and eider ducks (Grebmeier 2012). Understanding the seasonal reproductive patterns of bivalves can shed light on the impacts of environmental change on their biodiversity, as well as the species that consume them.

Pelagic larvae of marine bivalves follow two broad larval developmental modes, planktotrophy and lecithotrophy (Ockelmann 1962). Planktotrophic larvae feed on plankton in order to grow and reach a metamorphic stage, whereas lecithotrophic larvae rely on energy storage of maternal origin until metamorphosis or even beyond (for discussion see; Thorson 1946; Jablonski 1968; Thatje 2012). In the case of bivalves, the ability to feed during larval development may allow planktotrophic larvae to survive a longer duration in the water column than lecithotrophic larvae, which rely on endotrophic food sources of maternal origin (Ockelmann 1962). However, active feeding also implies that larvae may be more heavily affected by seasonality and the associated changes in the availability of food, including periods of starvation (Vance 1973; Weslawski et al. 1991).

The timing and duration of invertebrate reproduction and larval life cycle is influenced by environmental factors that vary seasonally, like temperature, salinity and light intensity (Weslawski et al. 1988; Günther and Fedyakov 2000; Schlüter and Rachor 2001). Response to environmental cues is species-specific and often related to the influence of physiological (genetic) inheritance of reproductive life history traits (Walker and Heffernan 1994). Traditionally, the study of the effect of seasonality on reproductive traits in bivalve species was hampered by the difficulty in identifying larvae to low taxonomic levels (Clough and Ambrose 1997; Schlüter and Rachor 2001; Fetzer 2004; Timofeev et al. 2007). To date, few studies from the Arctic have managed to resolve larval taxonomy to genus or species level (Thorson 1936; Norden-Andersen 1984). Further difficulties in the identification of bivalve larval species arise from their small size, the common lack of distinguishable and consistent morphological features, as well as a vast number of development stages (Garland and Zimmer 2002). For this reason, DNA barcoding has often been suggested as a useful additional tool for identifying those taxa, which are problematic to delimit using morphometric techniques alone (Webb et al. 2006). Molecular methods may hold advantages over morphological approaches when identifying larval or juvenile stages (Hardy et al. 2011 and references therein) as these overcome difficulties evoked from the frequent lack of unique morphometric characteristics separating species (Larsen et al. 2007). Consequently, the combination of
DNA barcoding and morphometric techniques has fundamentally strengthened the identification of species in previous polar taxonomic studies and should be considered standard for a more robust taxonomic resolution (Garland and Zimmer 2002; Sewell et al. 2006; Webb et al. 2006; Heimeier et al. 2010).

To compare the seasonality, and identify reproductive patterns of bivalve larval species in Arctic coastal areas, we present data on the occurrence of bivalve larvae from a study carried out in Adventfjorden, Svalbard $\left(78^{\circ} 15^{\prime} 60^{\prime \prime} \mathrm{N}\right.$ $15^{\circ} 31^{\prime} 80^{\prime \prime} \mathrm{E}$ ), over a 14-month time period (December 2011 to January 2013). We applied DNA barcoding of the mitochondrial 16S r RNA gene and morphological techniques in order to identify bivalve larvae to the lowest taxonomic levels. This paper discusses the macroecology linked to the seasonal dynamics of early ontogenetic stage bivalve species within a high Arctic fjord, all larval species of which were previously unidentified within the sampling region.

\section{Materials and methods}

\section{Sampling site}

The sampling locality of this study is situated within a high Arctic fjord, at the mouth of Adventfjorden $\left(78^{\circ} 15^{\prime} 60^{\prime \prime} \mathrm{N}\right.$, $\left.15^{\circ} 31^{\prime} 80^{\prime \prime} \mathrm{E}\right)$, part of the largest fjord system in Spitsbergen, Isfjorden (Fig. 1). The climate in Western Svalbard is relatively mild in comparison with similar latitudes elsewhere in the Arctic due to the influence of warm ocean currents (Cottier et al. 2005). Adventfjorden is influenced by both warm and saline Atlantic water, entering via Isfjorden from the West Spitsbergen current, and also colder Arctic water masses, which are mainly produced through more local processes (Nilsen et al. 2008). Seasonal variations in the water masses reaching the fjord are related to seasonal climate (Cottier et al. 2005). The benthic habitat of Adventfjorden consists of soft muddy sediment with some peripheral hard substrate (Brandner, pers. observation; Wlodarska-Kowalczuk et al. 2007). These habitat types are commonly found in the inner parts of high Arctic fjords (Kaczmarek et al. 2005; Wlodarska-Kowalczuk et al. 1998; Caroll and Ambrose 2012) allowing a variety of soft and hard bottom invertebrate species to occur.

Samples were obtained at the IsA (Isfjorden, Adventfjorden) time series station, between December 2011 and January 2013 as described by Stübner et al. (2016). Zooplankton samples were acquired once a fortnight, using a Working Party II (WPII) net of $63 \mu \mathrm{m}$ mesh size (Tranter 1968). Two vertical hauls were conducted, during the daytime, at each depth interval of $65-25 \mathrm{~m}$ and $25-0 \mathrm{~m}$ at a rate 


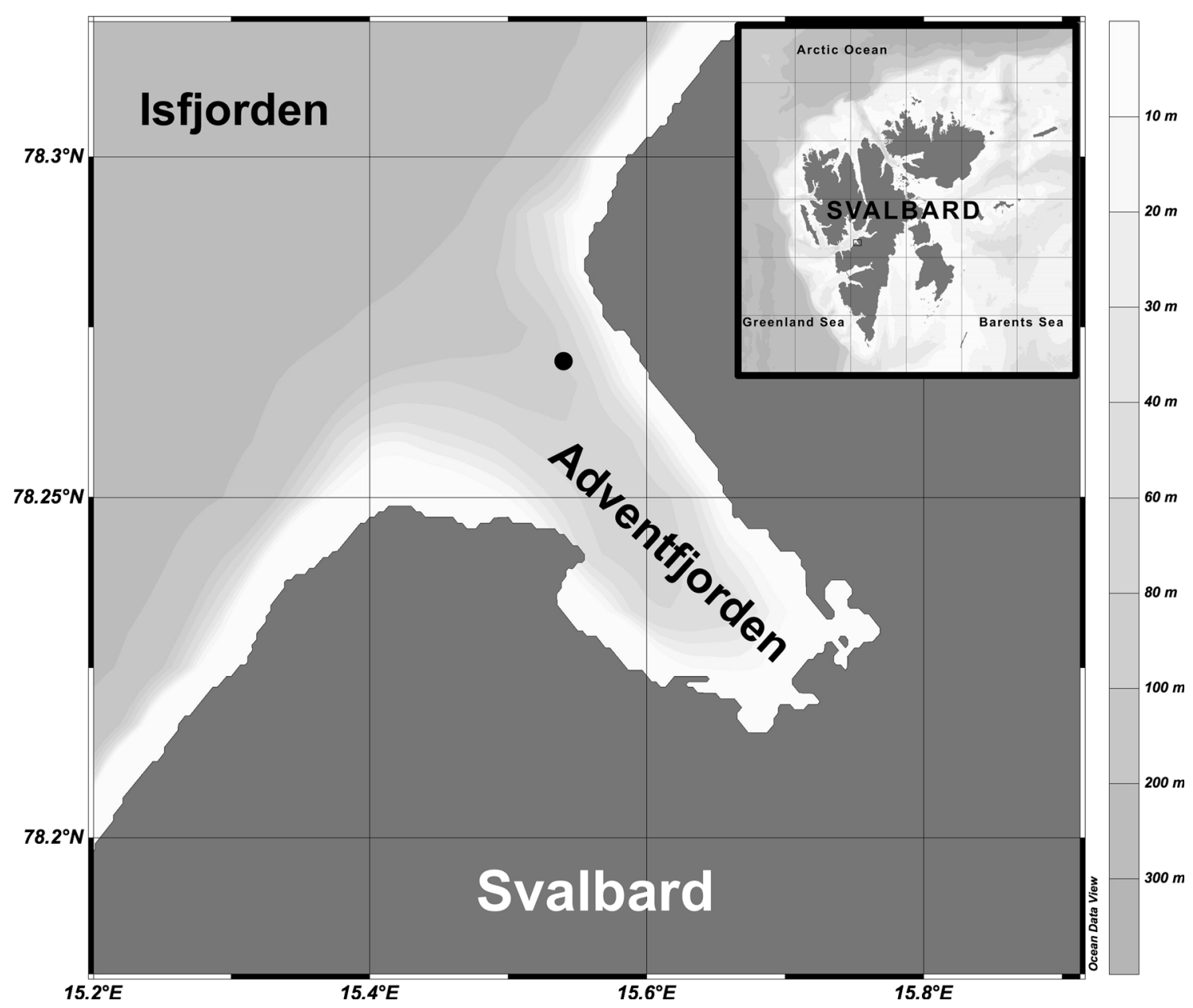

Fig. 1 Map of Svalbard and Adventfjorden (inset in black square on Svalbard map) showing the locality of the sampling station (black dot on inset map, $78^{\circ} 15^{\prime} 60^{\prime \prime} \mathrm{N}, 15^{\circ} 31^{\prime} 80^{\prime \prime} \mathrm{E}$ )

speed of $0.25-0.5 \mathrm{~ms}^{-1}$. One sample from each depth interval was fixed in $4 \%$ (final concentration) formalin buffered with hexamine, for quantitative community analysis. The formalin-fixed quantitative samples were sent to the Institute for Oceanography, Polish Academy of Sciences (IOPAS), for an analysis of the zooplankton community. Abundances were calculated assuming a $100 \%$ filter efficiency of the WPII net for zooplankton. The second sample was fixed in $75 \%$ ethanol for DNA analysis. Salinity and temperature data were collected at the sampling station before the WPII hauls using a conductivity/temperature/ depth (CTD) profiler (SAIVSD204). Chlorophyll $a$ samples were obtained using a 10-L Niskin bottle lowered to depths of 5, 15, 25 and $60 \mathrm{~m}$ during each sampling and processed according to methods in Stübner et al. (2016).

\section{Specimen collection and preparation}

Adult bivalve specimens collected in Svalbard waters (Table 1) using a triangular dredge were identified based on their morphology. Where possible, five specimens from each species were randomly selected for sequencing of the mitochondrial 16S r RNA gene (16S) to add Arctic taxa to that available in GenBank (Table 1).

A total of 14 ethanol-fixed plankton samples-obtained between December 2011 and January 2013 (Online Resource 1)—were investigated microscopically using a Leica MZ16 stereomicroscope, in order to pick out bivalve larvae for identification. Shell morphology, such as shape and developmental stage, was analysed according to literature (Loosanoff et al. 1966; Chanley and Andrews 1971; Kasyanov et al. 1998) in order to identify distinct larval morphological types. Special focus was given to identifying the stages of larval development, D-shaped veliger, transitional veliger or eyed pediveliger, according to Savage and Goldberg (1976). Sample permitting up to five individuals of each larval bivalve morphological type was picked from each month over the sampling period for DNA barcoding, to enable an analysis of larval occurrence and development. A total of 150 bivalve larvae were obtained 
Table 1 List of the species examined, including location of collection ( $S A$ Svalbard Archipelago, $B$ Barentsburg, $H$ Hinlopen, $K$ Kongsfjorden, $A$ Adventfjorden); 16S mitochondrial rRNA sequence length and GenBank accession numbers (see also Online Resource 1)

\begin{tabular}{|c|c|c|c|c|c|c|}
\hline Classification & Species & $\begin{array}{l}\text { Source } \\
\text { location }\end{array}$ & $\begin{array}{l}\text { Life history } \\
\text { stage }\end{array}$ & $\begin{array}{l}\text { Sequence length } \\
\text { (base pairs) }\end{array}$ & $\begin{array}{l}\text { Voucher } \\
\text { IDs }\end{array}$ & $\begin{array}{l}\text { Accession No. } \\
\text { (DDBJ) }\end{array}$ \\
\hline \multicolumn{7}{|l|}{ Pteriomorphia } \\
\hline Pectinidae & Chlamys islandica & SA & Adult & 586 & $56 \mathrm{IG} 71$ & KR827548 \\
\hline \multicolumn{7}{|l|}{ Mytiloida } \\
\hline \multirow[t]{2}{*}{ Mytilidae } & Dacrydium vitreum & SA & Adult & 470 & $56 I G 59$ & KR827550 \\
\hline & Musculus discors & SA & Adult & 478 & $56 \mathrm{IG} 58$ & KR827553 \\
\hline \multicolumn{7}{|l|}{ Veneroida } \\
\hline \multirow[t]{6}{*}{ Cardiidae } & Ciliatocardium ciliatum & $\mathrm{B}$ & Adult & 463 & $6 \mathrm{IG} 84$ & KR827466 \\
\hline & Ciliatocardium ciliatum & B & Adult & 463 & $56 \mathrm{IG} 97$ & KR827467 \\
\hline & Ciliatocardium ciliatum & $\mathrm{H}$ & Adult & 463 & $56 \mathrm{IG} 90$ & KR827468 \\
\hline & Ciliatocardium ciliatum & $\mathrm{H}$ & Adult & 463 & $56 \mathrm{IH} 03$ & KR827469 \\
\hline & Serripes groenlandicus & B & Adult & 464 & $56 I G 85$ & KR827479-80 \\
\hline & Serripes groenlandicus & A & Larva & 464 & ISAMB080 & KR827481 \\
\hline \multicolumn{7}{|l|}{ Myoida } \\
\hline \multirow[t]{3}{*}{ Myidae } & Mya truncata & $\mathrm{H}$ & Adult & 467 & $56 I G 87$ & KR827478 \\
\hline & Mya truncata & A & Larva & 478 & ISAMB035 & KR827484 \\
\hline & Mya sp. & A & Larva & 498 & ISAMB076 & KR827483 \\
\hline \multicolumn{7}{|l|}{ Euheterodonta } \\
\hline \multirow[t]{14}{*}{ Hiatellidae } & Hiatella arctica & $\mathrm{H}$ & Adult & 476 & $56 \mathrm{IG} 81$ & KR827470 \\
\hline & Hiatella arctica & $\mathrm{H}$ & Adult & 476 & $56 I G 80$ & KR827471 \\
\hline & Hiatella arctica & $\mathrm{H}$ & Adult & 476 & $56 \mathrm{IG} 79$ & KR827472 \\
\hline & Hiatella arctica & $\mathrm{H}$ & Adult & 476 & $56 \mathrm{IG} 78$ & KR827473 \\
\hline & Hiatella arctica & $\mathrm{H}$ & Adult & 476 & $56 \mathrm{IG} 77$ & KR827474 \\
\hline & Hiatella arctica & $\mathrm{H}$ & Adult & 476 & $56 I G 91$ & KR827475 \\
\hline & Hiatella arctica & $\mathrm{H}$ & Adult & 476 & $56 \mathrm{IG} 96$ & KR827476 \\
\hline & Hiatella arctica & $\mathrm{K}$ & Adult & 481 & $56 \mathrm{IG} 82$ & KR827477 \\
\hline & Hiatella arctica- Haplotype 1 & A & Larva & 442 & ISAMB007 & KT371426 \\
\hline & Hiatella arctica- Haplotype 2 & A & Larva & 442 & ISAMB019 & KT371427 \\
\hline & Hiatella arctica- Haplotype 3 & A & Larva & 442 & ISAMB065 & KT371428 \\
\hline & Hiatella arctica- Haplotype 4 & A & Larva & 442 & ISAMB103 & KT371429 \\
\hline & Hiatella arctica- Haplotype 5 & A & Larva & 442 & ISAMB069 & KT371430 \\
\hline & Hiatella arctica- Haplotype 6 & A & Larva & 442 & ISAMB012 & KR827482 \\
\hline \multirow[t]{3}{*}{ Thyasira } & Thyasira equalis & SA & Adult & 485 & $56 \mathrm{IG} 67$ & KR827554 \\
\hline & Thyasira gouldi & SA & Adult & 474 & $56 I G 64$ & KR827555 \\
\hline & Thyasira ferruginea & SA & Adult & 487 & $56 I G 62$ & KR827552 \\
\hline \multicolumn{7}{|l|}{ Nucilida } \\
\hline Nuculidae & Ennucula tenuis & SA & Adult & 518 & $56 \mathrm{IG} 61$ & KR827551 \\
\hline
\end{tabular}

for genetic analysis. No bivalve larvae were found in samples from December 2011, March 2012 or January 2013. Larvae were photographed using a Leica M205 C microscopic camera, and the length, width and hinge length (only D-shaped larvae) (Chanley and Andrews 1971) were measured to the nearest $1 \mu \mathrm{m}$. Each specimen was rinsed in $75 \%$ ethanol and Milli-Q water and then crushed and placed within a $1.5-\mathrm{ml}$ Eppendorf tube adding $30 \mu \mathrm{l}$ of Milli-Q water for molecular analysis. The samples were placed in $-80{ }^{\circ} \mathrm{C}$ for $24 \mathrm{~h}$ to break down the cells; specimens were stored at $-20^{\circ} \mathrm{C}$ for further analysis.

\section{Molecular work}

A variety of mitochondrial genes were trialled for amplification, including $12 \mathrm{~S}$ and $16 \mathrm{~S}$ ribosomal DNA, cytochrome oxidase subunit I (COI) and cytochrome b (cytB) using the primers and protocols of Plazzi and Passamonti 
(2010). DNA was extracted from tissue samples conserved in $70 \%$ alcohol using the DNeasy Tissue kit (Qiagen, USA) according to the manufacturer's recommendations. The only gene that had good amplification success, when tested on the crushed larvae extracts, was $16 \mathrm{~S}$, and therefore, we used this gene for barcoding the bivalve larvae and adults. The primers used were the conserved $16 \operatorname{Sar}(34)\left(5^{\prime}-\right.$ CGCCTGTTTATCAAAAACAT-3') and $16 \mathrm{SbrH}(32)\left(5^{\prime}-\right.$ CCGGTCTGAACTCAGATCACGT-3') (Palumbi 1994). PCR was performed in a total volume of $25 \mu$ including, $1 \mathrm{U}$ of DreamTaq polymerase, $0.2 \mu \mathrm{M}$ of each $\mathrm{dNTP}, 1 \times$ DreamTaq buffer, $0.2 \mu \mathrm{M}$ of forward $(16 \mathrm{SbrH}(32))$ and reverse $(16 \operatorname{Sar}(34))$ primers and $4 \mu \mathrm{l}$ of crushed specimen (larvae) or extracted DNA (adults). The PCR was carried out in an Eppendorf mastercycler epigradient $S$ under the following protocol: an initial denaturation for $3 \mathrm{~min}$ at $94{ }^{\circ} \mathrm{C}$, then 35 cycles of denaturation for $30 \mathrm{~s}$ at $94^{\circ} \mathrm{C}$, annealing for $30 \mathrm{~s}$ at $47^{\circ} \mathrm{C}$ followed by extension for $1 \mathrm{~min}$ at $72{ }^{\circ} \mathrm{C}$, then $5 \mathrm{~min}$ at $72{ }^{\circ} \mathrm{C}$ and then a cooling step at $10{ }^{\circ} \mathrm{C}$ (Plazzi and Passamonti 2010). Visualisation and quality control of PCR products were undertaken by gel electrophoresis in a $1.5 \%$ agarose gel at $210 \mathrm{~V}$ for $10 \mathrm{~min}$. Weak banding of the PCR products resulted in a re-amplification, using a 10x dilution of the PCR product and the same protocol and recipe as initially used. The resultant reamplifications combined with the successful initial amplifications provided 110 positive larval amplicons and 26 positive adult amplicons.

Prior to sequencing, all PCR products were purified using the EZNA pure cycle PCR kit (Omega Bio-tek Inc., USA). The amplified products were Sanger sequenced at either GATC Biotech AG or the Centre of Ecological and Evolutionary Synthesis (CEES), University of Oslo, using the reverse primer for unknown larvae, to confirm their identity before bidirectional sequencing, and both primers for adult sequences. After quality control 74 sequences were retained from the 110 positive larval amplicons (67.3\% sequencing success rate). Sequences were assigned a taxonomic name, and the PCR product of seven specimens, at least one from each larval taxon, was sent for forward primer sequencing (Online Resource 2).

\section{Morphometric support for DNA barcoding}

Morphometric features of larvae (picked from the ethanolfixed sample for DNA barcoding) were described by analysis of the photomicrographs collected for each specimen and with the use of literature (Lebour 1938; Chanley and Andrews 1971; Savage and Goldberg 1976). A diagram showing the size relationship between distinct taxonomic groups allows visual analysis of differences between larval taxa photomicrographs (Fig. 2).

\section{Data analysis}

The sequences were manually screened for quality and erroneously called bases using Geneious v 5.4 (Drummond et al. 2011). Contigs were combined for all samples of which both forward and reverse sequences were obtained (Table 1, Online Resource 2). Bivalve sequences downloaded from NCBI (accessed 15 July 2015) were combined with the adult bivalve sequences obtained within this study, to develop a searchable local database. In order to visualise the relationships among the identified bivalves, all database and larval sequences were globally aligned using ClustalW (Thompson et al. 1994) and alignments were manually optimised according to the secondary structure of $16 \mathrm{~S}$ (Lydeard et al. 2000; Barucca et al. 2005). Unique larval sequences were blasted against the NCBI database and local database using BLAST 2.2.26+ (Zhang et al. 2000) (see Online Resource 2). A taxonomic identity was assigned to the species level when pairwise sequence identity was $99 \%$ or higher (Feng et al. 2011). The Kimura 2-parameter model (Kimura 1980) in MEGA v 6.06 (Tamura et al. 2013) was applied to evaluate genetic distances. A neighbour-joining tree was also created in MEGA v 6.06 (Tamura et al. 2013). Unique haplotypes of identified unique bivalve sequences were submitted to GenBank (Table 1).

Larval morphometric parameters of D-shaped larva (identified to species level by genetic barcoding) were compared using the multivariate statistical test, multiple analysis of variance (MANOVA) in R, to identify whether morphometric parameters could explain the variance between genera. Only D-shaped larvae were taken into account because of the difficulty in species identification during this stage using the limited keys available. Descriptive statistics were applied to morphometric parameters (hinge length, shell length and width) of D-shaped larvae in the form of a linear discriminant analysis, in order to create a model for classifying unidentified D-shaped larvae. The prior assumptions of the test were met using the box $\mathrm{M}$ test as a comparison of the log determinants for variance-covariance (Box's $\mathrm{M}, M=9.426 F_{(10)}=0.533, p=0.867$ ), where $M$ should not be significant to show similarity. Wilks' lambda test for analysis of variance was applied to the predictors (morphometric parameters) and groups (genera which were identified by DNA barcoding) within the linear discriminant analysis to determine which predictors were significant for the classification of individuals. The linear discriminants were applied to unidentified D-shaped larvae to classify them into the genera that were identified by molecular means.

In order to test the relationship between pelagic bivalve larval abundance and oceanographic parameters, Spear- 
man's rank correlation test was applied, separately to each environmental variable (salinity, temperature and chlorophyll $a$ concentration), using the software package R (Rstudio 2012). The dependent variable (larval abundance) did not meet the assumptions of the parametric correlation tests due to heteroscedasticity.

\section{Results}

\section{Molecular analysis}

The length of the amplified $16 \mathrm{~S}$ fragment sequenced ranged from 302 to 586 base pairs. The 26 adult bivalve sequences obtained represented 11 taxa ( 21 high-quality adult sequences were submitted to National Center for Biotechnology Information (NCBI), Table 1) not found in NCBI (1-8 samples per taxon). Bivalve specimens showed within-species distances of $0-0.008(n=61)$ and betweenspecies distances of $0.061-0.851 \quad(n=12)$, calculated using the K2P parameter (Online Resources 3, 4).

A total of 74 larval DNA sequences were identified using genetic barcoding. The BLAST search against the local database assigned the larval sequences to 4 taxa (Table 2, Online Resource 2). One taxon could not be assigned to a species, but had $97 \%$ similarity to Mya truncata and $91 \%$ to $M$. arenaria, and was assigned to Mya sp. Sequences were assigned by DNA barcoding of $16 \mathrm{~S}$ to 4 species: Hiatella arctica (Linnaeus 1767) $(n=56)$, M. truncata (Linnaeus 1758) $(n=6)$, Mya sp. $(n=4)$ and Serripes groenlandicus (Mohr 1786) $(n=8)$. $H$. arctica was represented by six possible larval haplotypes, which had singular or multiple nucleotide polymorphisms, showing a divergence of (0.004-0.008) within the species.

\section{Morphological analysis}

The morphology of all genetically identified species was similar, and distinguishable characteristics were difficult to

Table 2 Classification of the number of sequences $(n)$ assigned to each species according to distance-based comparison, the percentage of identical sites with standard deviation (av. \% identical sites for identify between them, making size relationships a key taxonomic trait (Fig. 2). Size-related intergenera variation (Fig. 2) shows that Mya spp. and S. groenlandicus both develop an umbone (this is when a larva metamorphoses into the transitional stage) at a larger size than $H$. arctica. They are also generally larger throughout their pelagic life cycle. In a morphological comparison between the two Mya species, there appeared to be no difference in morphological characteristics of the D-shaped larval stage (Fig. 2). In the transitional larval stage, Mya sp. had a slightly flatter and broader umbone. However, this may be due to the slightly smaller size of Mya sp. specimens found. Consequently, both species were combined for further analysis.

The D-shaped larval stage was difficult to classify taxonomically because of their average size of $157 \mu \mathrm{m} \times 135 \mu \mathrm{m}$, below sizes previously stated as viable for taxonomic delineation (Larsen et al. 2007, and references therein). Only 9 of 35 D-shaped larval specimens could be distinguished by morphological shape characteristics described in literature (Chanley and Andrews 1971). Measured taxonomic characteristics (height, length and hinge length) of the D-shaped larvae between the three genetically identified genera differ significantly (MANOVA, Wilks' test, $F_{(2,20)}=16.413, p<0.0001$ ) (Online Resource 5). The discriminant function revealed a significant association between groups and all predictors (Wilks' lambda, $W=0.042, \chi_{(8)}^{2}=58.512, p<0.0001$ ), accounting for $98.5 \%$ of between-group variability. Although closer analysis of the structure matrix revealed only 3 significant predictors with strong positive correlation, namely length $(r=0.766)$, height $(r=0.671)$ and hinge length $(r=0.766)$, with the variable 'date' as a non-significant poor predictor $(r=-0.67)$ (Table 3$)$, the canonical linear discriminant scores retain distinct grouping between Hiatella sp. and Serripes sp. and less distinctly between Serripes sp. and Mya spp., but not between $\mathrm{Hi}$ atella sp. and Mya spp. In a comparison of the group centroids, there is no overlap between the groups (Online Resource 5), and the relative distance between them shows

species calculated from top BLAST hit of each specimen) for the BLAST algorithm search and alignment within local database and the respective taxon

\begin{tabular}{lrlr}
\hline Taxon & $n$ & Av. percentage identical sites \\
\cline { 3 - 4 } & & BLAST & Local database \\
\hline Hiatella arctica & 56 & $96.09 \pm 1.33$ & $99.6 \pm 0.33$ \\
Mya truncata & 6 & $89.00 \pm 0.00$ & 100 \\
Mya spp. & 4 & $91.00 \pm 0.00$ & 97.1 \\
Serripes groenlandicus & 8 & $89.00 \pm 0.00$ & 100 \\
\hline
\end{tabular}


that there will be a higher error rate in the classification between Mya spp. and Hiatella sp. than for the group Serripes sp. The cross-validated classification showed that the model correctly classified overall $73.9 \%$, which is above what was necessary to satisfy the pre-set misclassification limit $(58 \%$, the probability of selecting a group plus $25 \%$ ).

\section{Seasonality}

The abundance of bivalve larvae varied strongly between the seasons (Fig. 3). The highest total number of individuals was recorded in July $\left(81,140\right.$ ind. $\left.\mathrm{m}^{-3}\right)$. During the winter months December and February, no larvae were recorded in the zooplankton quantitative samples, with a low abundance of 7 ind. $\mathrm{m}^{-3}$ in January. Larvae appeared in the water column in late March (22 ind. $\mathrm{m}^{-3}$, Fig. 3) and dominated the zooplankton during the months of June and July ( 81 and $84 \%$ of total zooplankton abundance).

There was no tendency for the abundance of bivalve larvae $\left(\mathrm{m}^{-3}\right)$ to increase or decrease with temperature (Spearman's rank correlation, $\rho_{19}=0.10, p>0.1$ ) or salinity (Spearman's rank correlation, $\rho_{19}=0.01, p>0.1$ ); however, chlorophyll $a$ concentration did have a significant positive association with abundance of bivalve larvae (Spearman's rank correlation, $\rho_{19}=0.76, p<0.01$ ) (Fig. 3).

The identified bivalve taxonomic groups vary in seasonality and occurrence of developmental stages (Fig. 3). The D-shaped larval stage can be used as an indicator for relative spawning periods, because it is the first larval stage after spawning (Sullivan 1948). Multiple spawning events were indicated for all taxonomic groups except for $S$. groenlandicus (Fig. 3). The D-shaped larvae of H. arctica and $M$. truncata were observed in two distinct cohorts (Fig. 3). The first cohort for $H$. arctica and the two Mya species occurs during the peak in chlorophyll $a$ concentration $\left(8.094 \mu \mathrm{g} \mathrm{L}^{-1}\right)$ in May 2012. The secondary cohort occurs in September when chlorophyll $a$ levels were low $\left(0.281 \mu \mathrm{g} \mathrm{L}^{-1}\right)$. H. arctica larvae were present from May 2012 to January 2013. Eyed-pediveliger stages of $H$. arctica were present from July to November 2012 and then, again, in December 2012. M. truncata appear to be present from May to October 2012 and have D-shaped larvae present from May to August 2012 and a shorter secondary planktonic appearance, of 1 month in September (Fig. 3). Later stages were only present in August (Fig. 3), Mya sp. shows the same timing in planktonic appearance as both $H$. arctica and $M$. truncata, but transitional developmental stages occurred in September and October. In contrast, $S$. groenlandicus was present in the summer months, June 2012 and later in August 2012; D-shaped larvae occurring in June 2012 coincided with an intermediate peak in chlorophyll $a$ concentration $\left(4.71 \mu \mathrm{g} \mathrm{L}^{-1}\right)$. Transitional larval stages only occurred in August 2012 (Fig. 3).

\section{Discussion}

\section{Identifying Arctic bivalve larvae}

This study successfully applied genetic barcoding in combination with morphometric identification to better resolve the bivalve larval meroplankton from an Arctic fjord of Spitsbergen. The combination of a local BLAST search database and distance-based techniques (Feng et al. 2011; Liu et al. 2011) as a DNA barcoding method led to the classification of four larval taxa, H. arctica, M. truncata, Mya sp. and S. groenlandicus. Three of the four bivalve taxa identified using genetic barcoding could also be distinguished through morphological characteristics, and statistically significant morphological differences of the species' D-larva were found (Fig. 2). The combination of genetic and morphological analyses enabled us to provide novel descriptions of the phenotypes of larval development stages of the species $H$. arctica, M. truncata and $S$. groenlandicus within the Arctic (Fig. 2).

The use of the most successfully amplified gene 16S restricted the amount of reference data for the assignment of sequences to species, because the available database for $16 \mathrm{~S}$ is less comprehensive than that for the $\mathrm{COI}$ in polar regions. For species in Isfjorden (Rozycki 1993), 16S was listed for 2 in 36 species, whereas $\mathrm{CO} 1$ for 17 in 36 species

Table 3 Results from the linear discriminant analysis showing, which predictors (date, length, height and hinge length) influence the variance between group means (groups: Hiatella sp., Mya spp.

Serripes sp.) of D-shaped larvae identified by DNA barcoding of the mitochondrial $16 \mathrm{~S}$ gene, where all predictors were significant except for date ( $D f$ degrees of freedom)

\begin{tabular}{llrrrr}
\hline Independent variable & Wilks' lambda & $F$ & Df1 & Df2 & Significance \\
\hline Date & 0.903 & 1.074 & 2 & 20 & 0.361 \\
Length & 0.111 & 80.126 & 2 & 20 & 0.000 \\
Height & 0.118 & 74.653 & 2 & 20 & 0.000 \\
Hinge length & 0.088 & 104.249 & 2 & 20 & 0.000 \\
\hline
\end{tabular}


Fig. 2 Relative sizes $(\mu \mathrm{m})$ of the development stages (primary D-shaped larval stage to eyed-pediveliger stages) of pelagic bivalve larvae (between 275 and $450 \mu \mathrm{m}$ in length);

Hiatella arctica, Mya sp. Mya truncata and Serripes

groenlandicus, which have been identified using DNA barcoding of the mitochondrial $16 \mathrm{~S}$ gene.

The anterior edge of all specimens is aligned to the right of the figure. Photomicrographs were taken using a Leica M205 $\mathrm{C}$ microscopic camera

\begin{tabular}{cc}
$\begin{array}{c}\text { Length } \\
(\mu \mathrm{m})\end{array}$ & $\begin{array}{l}\text { Hiatella } \\
\text { arctica }\end{array}$ \\
\hline 100 & $112 \times 95$
\end{tabular}

125

150
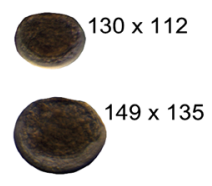

Mya sp.

Taxa

Mya Serripes

truncata groenlandicus

175
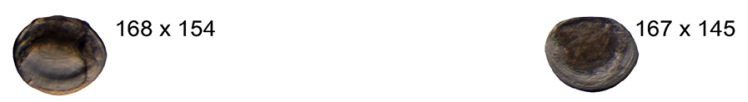

200

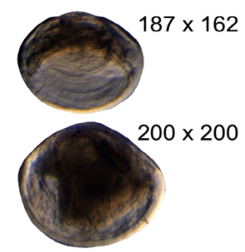

225

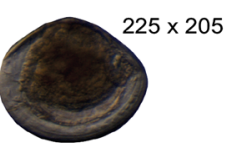

250

275

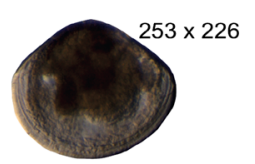

$140 \times 120$

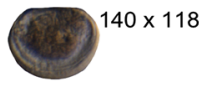

$127 \times 109$
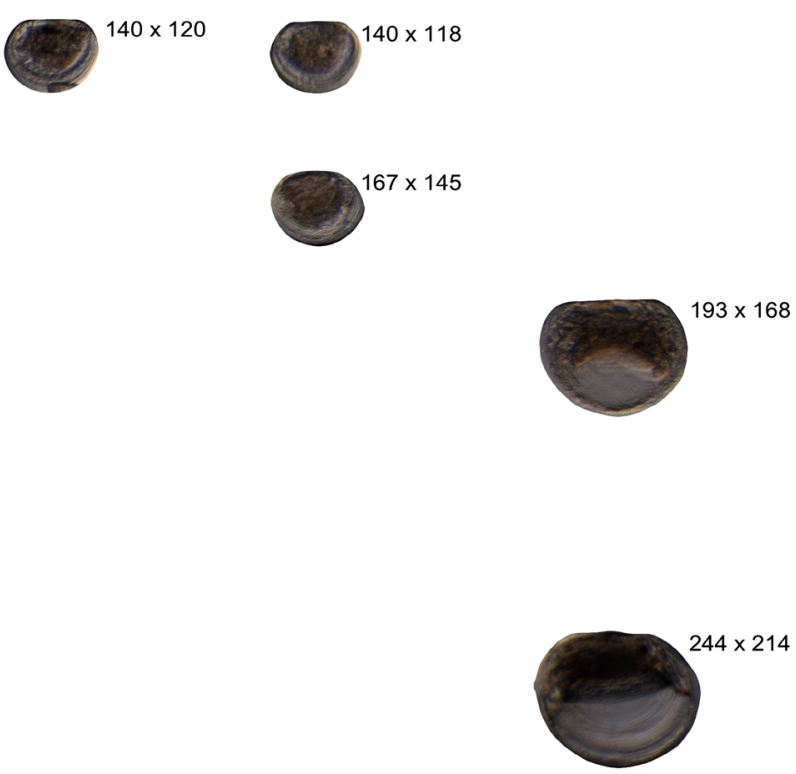

300

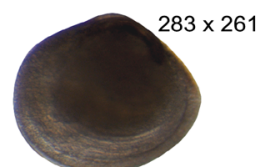

325
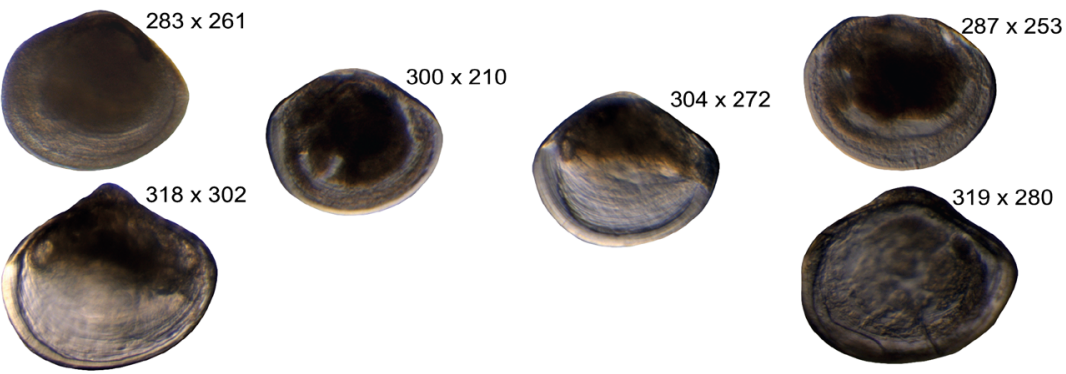

350

375

400

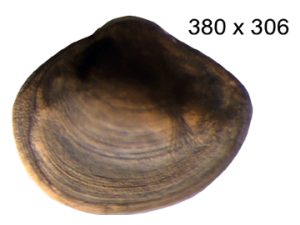


Fig. 3 Seasonality of bivalve larvae and phytoplankton; (a) intra-annual variability in abundance (ind. $\mathrm{m}^{-3}$ ) of bivalve larvae, (b) comparison of early ontogeny between the species, Mya truncata, Mya sp. Hiatella arctica and Serripes groenlandicus from the high Arctic fjord, Adventfjorden (considering only larvae identified genetically). c Intraannual variability in chlorophyll $a$ concentration (whole line) (a proxy for phytoplankton biomass) and temperature (dashed line)
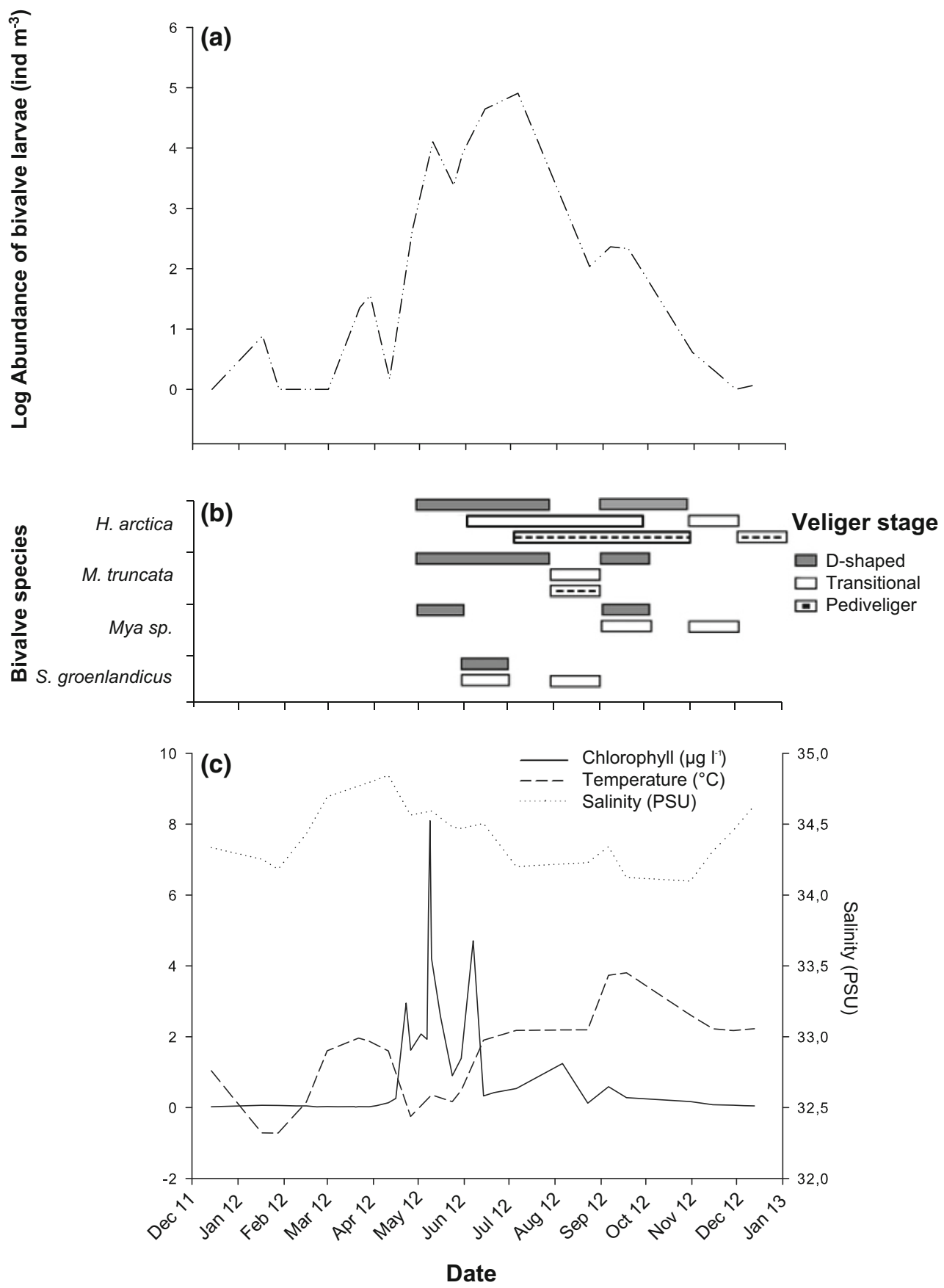

(GenBank accessed on 31 March 2015). The assignment of sequences to species can be achieved by a distance-based barcoding method based on the assumption that variation within a species is lower than variation between species (Hebert et al. 2003; Meyer and Paulay 2005). This difference in variation creates a so-called barcoding gap (Hebert et al. 2003). However, there is a variance in the barcoding gap between taxonomic groups and the gene used that is a potential problem (Meyer and Paulay 2005). This could be overcome with thorough sampling to establish thresholds specific to the taxonomic group being studied and sampling location, which was not possible within the scope of this study. We witnessed a barcoding gap of an order of magnitude; however, the sample size was low, with some species represented by single specimen. Limited comparative data within the study and the Arctic in general led to the use of previously established bivalve $16 \mathrm{~S}$ species thresholds (Feng et al. 2011; Liu et al. 2011).

The larvae classified as Mya sp. could not be distinguished morphologically (Fig. 2), only genetically through 
DNA barcoding, a standard tool to identify zooplankton taxa with widespread or disjoint distributions (Knowlton 2000; Bucklin et al. 2007; Thatje 2012). Possibilities for the similarity between the two Mya morphotypes could be that M. truncata and Mya sp. are the same species but presenting large intraspecific variation in the $16 \mathrm{~S}$ gene ( $2.8 \%$ intraspecific variation, $0.017 \mathrm{~K} 2 \mathrm{P}$ distance). Such explanation was previously discussed for some widespread species such as the copepod Nannocalanus minor, which had COI sequences differences of $\sim 12 \%$ (Bucklin et al. 1996). Cryptic speciation is another alternative explanation and has been recorded for $M$. truncata in previous Arctic studies, but the evidence presented remained controversial (Petersen 1999; Layton et al. 2014).

The use of molecular techniques was particularly advantageous for classifying D-shaped larvae, which is a life stage that is difficult to identify because of their similarity and size (Hendriks et al. 2005). Through barcoding, specimens down to a size of $112 \mu \mathrm{m} \times 95 \mu \mathrm{m}$ (length $\times$ height) could be identified and classified. The genetic identifications of D-shaped larvae could be classified down to genus level using dimensions, an important tool for identifying veliger stages of bivalves (Chanley and Andrews 1971; Hendriks et al. 2005). Morphological separation between Mya spp. and Hiatella sp. larvae was less significant than between Serripes sp. larvae and all other genera. The morphological similarity between Mya sp. and Hiatella sp. larvae has been reported in previous studies conducted at lower latitudes (Savage and Goldberg 1976). Since each method holds its own limitations, the combination of molecular and morphological techniques makes identification more robust.

\section{Seasonality of Arctic bivalve larvae}

Few studies have been undertaken to study the abundance, diversity and timing of meroplankton in the Arctic (e.g. Thorson 1936; Norden-Andersen 1984; Weslawski et al. 1988; Fetzer 2004; Kuklinski et al. 2013). In accordance with our results, meroplankton occurrences have earlier been shown to exhibit a strong seasonal pattern at polar latitudes, with highest abundances of bivalve larvae in summer (Weslawski et al. 1988; Stanwell-Smith et al.1999; Bowden et al. 2009; Kuklinski et al. 2013; Fig. 3). The strong association of bivalve larval abundance in Adventfjorden with the phytoplankton biomass, estimated through chlorophyll $a$ concentrations, suggests that peaks in larval abundance are linked to shifts in food availability (Spearman's rank correlation, $\left.\rho_{19}=0.76, p<0.01\right)$. This has also been demonstrated earlier for both bivalve larvae (Günther and Fedyakov 2000) and other groups (Stübner et al. 2016), in polar regions. In Adventfjorden, both phytoplankton and bivalve larval peaks were a month later in 2007 (Kuklinski et al. 2013) than in 2012 (this study). Such seasonal shifts can occur year after year, presenting interannual variation (Günther and Fedyakov 2000). Peaks in larval abundance are often delayed in relation to spawning events due to the time it takes for the larva to develop into a veliger (Pulfrich 1997). In Adventfjorden, the peak occurrence of bivalve larvae (July 2012) followed shortly after the phytoplankton bloom (May 2012). This suggests that food availability may be the main trigger for spawning (Starr et al. 1990) and a planktotrophic mode for bivalve larvae has been suggested in Adventfjorden (Stübner et al. 2016). Even though changes in water temperature are also known to coincide with the reproduction of marine bivalves (Chícharo and Chícharo 2000; Goeij and Honkoop 2003; Costa et al. 2012), this was not found in our study (Spearman's rank correlation, $\rho_{19}=0.01$, $p>0.1)$. Neither temperature (0-65 m water depth, mean range $\left.=1.3-4{ }^{\circ} \mathrm{C}\right) \quad$ (Spearman's rank correlation, $\left.\rho_{19}=0.01, p>0.1\right)$ nor salinity (34.1-34.8 psu) (Spearman's rank correlation, $\left.\rho_{19}=0.10, p>0.1\right)$ presented any clear patterns coinciding with larval occurrence (Fig. 3).

The accuracy of zooplankton sampling is often affected by patchiness in the distribution of plankton (Tranter 1968) and a range of other biological factors, e.g. diel vertical migrations, and dispersal of larvae. Thus, the results from our sampling, with only one replicate taken each time, have to be regarded with caution, and we may well have missed sampling further species that possess meroplanktonic larvae in the area under investigation. The sampling strategy employed in this study-once or twice per month-and the difficulty in identifying all of the specimens, means that we may have missed representing full developmental cycles of larvae present in the plankton, as well as the true diversity of pelagic bivalve larvae (Thorson 1950).

Species' or population-specific reproductive traits can influence larval occurrence (Günther and Fedyakov 2000; Cross et al. 2012; Philliphart et al. 2014), and thus, local macrobenthic communities are related to the observed pattern (Mileikovsky 1968; Kulikova et al. 2013). M. truncata and $H$. arctica are recorded as low-density species in Adventfjorden (Wlodarska-Kowalczuk et al. 2007; Pawlowska et al. 2011), and their presence is likely to be related to local populations. On the contrary, adult populations of $S$. groenlandicus are not known from studies undertaken in Adventfjorden, and larval occurrence may be a result of the pelagic dispersal of larvae by means of currents (Nilsen et al. 2008). Oceanographic parameters strongly influence meroplankton seasonality (Highfield et al. 2010), and currents are known to transport larval specimens away from adult populations and also into fjord systems (Mileikovsky 1968; Garland et al. 2002).

The seasonal occurrence of bivalve larvae shows variation in duration across $H$. arctica and $M$. truncata's 
biogeographic range (Fig. 4). In general, $H$. arctica's duration of occurrence is longer in populations at higher latitudes, and it is present in the water column for $1-2$ months at lower latitudes $\left(42-46^{\circ} \mathrm{N}\right)$ in comparison with 8 months at $56^{\circ} \mathrm{N}$ and in this study $\left(78^{\circ} \mathrm{N}\right)$ (Fig. 4). However, a study by Ockelmann (1958) showed only 2 months of larval presence at $78^{\circ} \mathrm{N}$. H. arctica is present in the water column between May and December at all latitudes and is shifted later in the year at lower latitudes, September and October (Kasyanov et al. 1998; Kulikova et al. 2013). A biannual spawning pattern was only seen in this study, and continuous spawning was seen in a lower latitude study (Flyachinskaya and Lesin 2006). M. truncata presents the same general latitudinal pattern as $H$. arctica; at high latitudes $M$. truncata is present for up to 5 months $\left(65^{\circ} \mathrm{N}\right.$ and $\left.78^{\circ} \mathrm{N}\right)$ in comparison with 2 months at lower latitudes $\left(42^{\circ} \mathrm{N}\right)$ (Fig. 4). M. truncata larvae have been found in the water column between April and November in all studies, with no distinct pattern of shifting occurrence with latitude. Previous studies at lower latitudes (Peter the Great Bay, Sea of Japan, Southern Adriatic) on both $H$. arctica and M. truncata have linked seasonality of larval occurrence to low temperatures, relative to local climate, between 13 and $15{ }^{\circ} \mathrm{C}$ (Kasyanov et al.1998; Günther and Fedyakov 2000; Kulikova et al. 2013) (Fig. 4), which is far above temperatures encountered in Adventfjorden (Fig. 2). $M$. truncata and $H$. arctica are both known to be psychrophilic species, meaning that they are capable of growth and reproduction at cold temperatures (Beer 2000). This might have allowed $M$. truncata and $H$. arctica to extend their geographic range into the Arctic and the study region, presenting cold-stenothermal conditions $\left(-1.3-4{ }^{\circ} \mathrm{C}\right)$ year round (Fig. 3).

The bivalve species in the fjords of Spitsbergen are a mix of Arctic and boreal species (Rozycki 1993; Pawlowska et al. 2011; Caroll and Ambrose 2012) that have variable biogeographic ranges. A latitudinal cline in the seasonality of reproduction has been reported in marine invertebrates (Bauer 1992). Over the boreal geographic range of $M$. truncata and $\mathrm{H}$. arctica, changes in larval seasonality can be seen (Figs. 3, 4). The duration of larval occurrence was much shorter at lower latitudes (1-2 months at $\left.42^{\circ} \mathrm{N}\right)$ (Fig. 3) compared to high latitudes (H.arctica: 8 months; M.truncata: 5 months), as also seen in other boreal bivalve species such as Macoma calcerea (Oertzen 1972).

Our observations of prolonged spawning during biannual events in spring (from May until August) and autumn (September to November) in M. truncata and H. arctica may be the result of multiple overlapping spawning periods. Individuals in some bivalve species, e.g. M. arenaria and $M$. balthica, can spawn at different times of the year dependent on sex and habitat (Cross et al. 2012; Philippart et al. 2014). The biannual spawning patterns witnessed may relate to the increase in phytoplankton biomass
Fig. 4 Comparison of intraannual bivalve larval occurrence, between (a) Hiatella arctica (b) Mya truncata, over part of their latitudinal range $\left(42^{\circ}-78^{\circ} \mathrm{N}\right)$, showing presence of bivalve larvae in the water column (black lines), spawning periods of bivalves (white blocks) and months not included in the study undertaken by the Author stated [grey blocks (NB some studies cover two sampling years)]

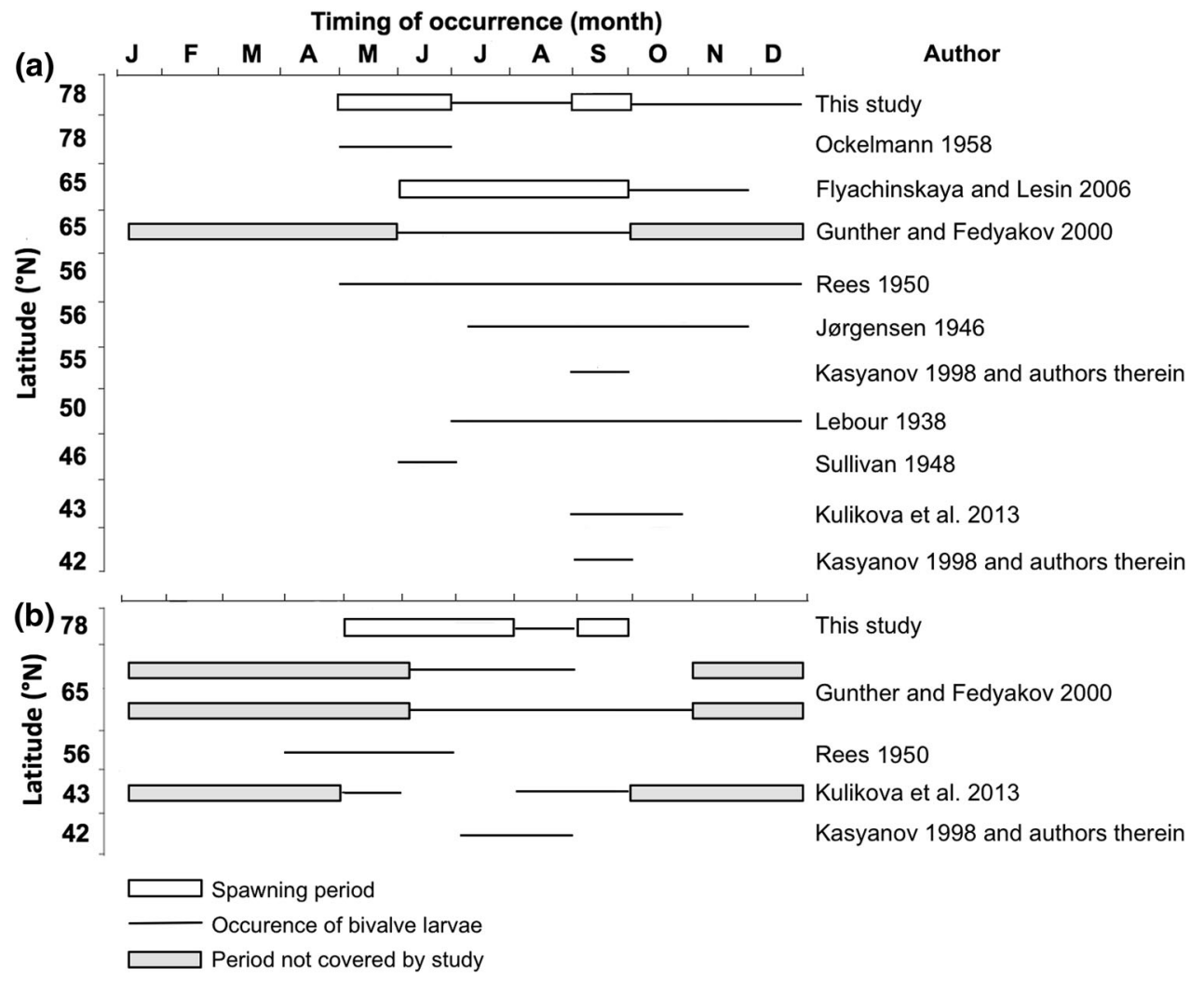


observed in spring and autumn. A greater understanding of bivalve reproductive cycles could explain patterns of occurrence of larvae with local environmental parameters.

Serripes groenlandicus is an Arctic circumpolar species (Royzcki 1992, and references therein) giving it a shorter latitudinal range than M. truncata and H. arctica (Petersen 1978; Günther and Fedyakov 2000). Though S. groenlandicus presence has not been confirmed for Adventfjorden, adults are known to occur in adjacent Isfjorden (Wlodarska-Kowalczuk et al. 1999). The reproductive cycle of $S$. groenlandicus was previously recorded to coincide with ice algal bloom, in March and April (Petersen 1978); however, in this study S. groenlandicus co-occurred with a phytoplankton bloom found in June. Larvae of $S$. groenlandicus are known to prevail in the plankton for only short periods of time (Günther and Fedyakov 2000), which is in agreement with our findings of a shorter presence in the water column (only in June and August) compared to H. arctica and Mya spp. (May to January).

We suggest that the difference in reproductive patterns seen between species is linked to their biogeographic range (Fetzer and Arntz 2008). Such knowledge may be key to understanding better how reproductive patterns of Arctic species may shift in response to climate-driven shifts in seasonality.

Acknowledgments Field sampling and sample analyses were supported by UNIS research funds and the Norwegian Research Council (www.forskningsradet.no) through MeroSeason I (Grant Number 219707/E10), Cleopatra II (Grant Number 216537) and the ConocoPhillips and Lundin Northern Area Program as part of the MicroFun project. Sample analysis was partly supported by the National Scientific Centre (Project Number 2736/UniPlankton/2013, www.ncn. gov.pl). The authors are grateful to the Svalbard Science Forum for the Arctic Field Grant 2013 to financially support collection of samples. We thank many colleagues from the Adventfjorden field campaign, Svalbard, who helped with sampling and processing samples for storage, with special mention to Miriam Marquadt, Stuart Thomson and Lars Frode Stangeland. We would also like to acknowledge Anna Vader for scientific advice.

Open Access This article is distributed under the terms of the Creative Commons Attribution 4.0 International License (http://crea tivecommons.org/licenses/by/4.0/), which permits unrestricted use, distribution, and reproduction in any medium, provided you give appropriate credit to the original author(s) and the source, provide a link to the Creative Commons license, and indicate if changes were made.

\section{References}

Barucca M, Olmo E, Capriglione T, Odierna G, Canapa A (2005) Taxonomic considerations on the Antarctic species Adamussium colbecki based on molecular data. Polarnet Tech Rep 1:53-57

Bauer RT (1992) Testing generalizations about latitudinal variation in reproduction and recruitment patterns with sicyoniid and caridean shrimp species. Invertebr Reprod Dev 22:193-202
Beer TL (2000) Pelagic larvae of bivalves in the meroplankton of the Velikaya Salma Inlet, Kandalaksha Bay, the White Sea. Oceanology 40:671-676

Bowden DA, Clarke A, Peck LS (2009) Seasonal variation in the diversity and abundance of pelagic larvae of Antarctic marine invertebrates. Mar Biol 156:2033-2047

Bucklin A, LaJeunesse TC, Curry E, Wallinga J, Garrison K (1996) Molecular genetic diversity of the copepod, Nannocalanus minor: genetic evidence of species and population structure in the N. Atlantic Ocean. J Mar Res 54:285-310

Bucklin A, Wiebe PH, Smolenack SB, Copley NJ, Beaudet JG, Bonner KG, Färber-Lorda J, Pierson JJ (2007) DNA barcodes for species identification of euphausiids (Euphausiacea, Crustacea). J Plankton Res 29:483-493

Carroll ML, Ambrose WG Jr (2012) Benthic infaunal community variability on the northern Svalbard shelf. Polar Biol 35:1259-1272

Chanley P, Andrews JD (1971) Aids for the identification of bivalve larvae of Virginia. Malacologia 1:45-119

Chícharo LMZ, Chícharo MA (2000) Short-term fluctuations in bivalve larvae compared with some environmental factors in a coastal lagoon (South Portugal). Sci Mar 64:413-420

Clough L, Ambrose W (1997) Infaunal density, biomass and bioturbation in the sediments of the Arctic Ocean. Deep-Sea Res 44:1683-1704

Costa FD, Aranda-Burgos JA, Cervino-Otero A, Fernandez-Pardo A, Louzan A, Novoa S, Ojea J, Martinez-Patino D (2012) Clam reproduction. In: Costa FD (ed) Clam fisheries and aquaculture. Nova Publishers, New York, pp 45-47

Cottier F, Tverberg V, Inall M, Svendsen H, Nilsen F, Griffiths C (2005) Water mass modification in an Arctic fjord through crossshelf exchange: the seasonal hydrography of Kongsfjorden, Svalbard. J Geophys Res 110:1978-2012

Cross ME, Lynch S, Whitaker A, O'Riordan RM, Culloty SC (2012) The reproductive biology of the softshell clam, Mya arenaria, in Ireland, and the possible impacts of climate variability. J Mar Biol. doi:10.1155/2012/908163

Drummond AJ, Ashton B, Buxton S, Cheung M, Cooper A, Duran C, Field M, Heled J, Kearse M, Markowitz S, Moir R, Stones-Havas Sturrock S, Thiere T, Wilson A (2011) Geneious v5.4. Available from http://www.geneious.com/

Feng Y, Li Q, Kong L, Zheng X (2011) DNA barcoding and phylogenetic analysis of Pectinidae (Mollusca: Bivalvia) based on mitochondrial COI and 16S rRNA genes. Mol Biol Rep 38:291-299

Fetzer I (2004) Reproduction strategies and distribution of larvae and juveniles of benthic soft-bottom invertebrates in the Kara Sea (Russian Arctic). The influence of river discharge on the structure of benthic communities: a larval approach. Dissertation, University of Bremen, p 242

Fetzer I, Arntz WE (2008) Reproductive strategies of benthic invertebrates in the Kara Sea (Russian Arctic): adaptation of reproduction modes to cold water. Mar Ecol Prog Ser 356:189-202

Flyachinskaya L, Lesin P (2006) Using 3D reconstruction method in the investigations of Bivalvia larval development (by the example of Hiatella arctica L.). Proc Zool Inst Russ Acad Sci 310:45-50

Garland E, Zimmer C (2002) Techniques for the identification of bivalve larvae. Mar Ecol Prog Ser 225:299-310

Garland ED, Zimmer CA, Lentz SJ (2002) Larval distributions in inner-shelf waters: the roles of wind-driven cross-shelf currents and diel vertical migrations. Limnol Oceanogr 47:803-817

Goeij P, HonKoop PJC (2003) Experimental effects of immersion time and water temperature on body condition, burying depth 
and timing of spawning of the tellinid bivalve Macoma balthica. Helgoland Mar Res 57:20-26

Grebmeier JM (2012) Shifting patterns of life in the Pacific Arctic and Sub-Arctic seas. Annu Rev Mar Sci 4:63-78

Günther CP, Fedyakov VV (2000) Seasonal changes in the bivalve larval plankton of the White Sea. Senckenberg Marit 30:141-151. doi:10.1007/BF03042963

Hardy SM, Carr CM, Hardman M, Steinke D, Corstorphine E, Mah C (2011) Biodiversity and phylogeography of Arctic marine fauna: insights from molecular tools. Mar Biodivers 41:195-210

Hebert PDN, Cywinska A, Ball SL, deWaard JR (2003) Biological identifications through DNA barcodes. Proc $R$ Soc $B$ 270:313-321

Hendriks IE, van Duren LA, Herman PMJ (2005) Image analysis techniques: a tool for the identification of bivalve larvae? J Sea Res 54:151-162

Heimeier D, Lavery S, Sewell MA (2010) Using DNA barcoding and phylogenetics to identify Antarctic invertebrate larvae: lessons from a large scale study. Mar Genom 3:165-177

Highfield JM, Eloire D, Conway DVP, Lindeque PK, Attrill MJ, Somerfield PJ (2010) Seasonal dynamics of meroplankton assemblages at station L4. J Plankton Res 32:681-691

Jablonski D (1968) Larval ecology and macroevolution in marine invertebrates. Bull Mar Sci 39(2):565-587

Jørgensen CB (1946) Reproduction and larval development of Danish marine bottom invertebrates. Medd Komm Danmarks Fish Havunders 4:277-311

Kaczmarek H, Wlodarska-Kowalczuk M, Legezynka J, Zajaczkowski M (2005) Shallow sublittoral macrozoobenthos in Kongsfjord, west Spitsbergen, Svalbard. Pol Polar Res 26:137-155

Kasyanov VL, Kryuchkova GA, Kulikova VA, Medvedeva LA (1998) Larvae of marine bivalves and echinoderms. Smithsonian institution libraries, Washington DC

Kimura M (1980) A simple method for estimating evolutionary rate of base substitutions through comparative studies of nucleotide sequences. J Mol Evol 16:111-120

Knowlton N (2000) Molecular genetic analyses of species boundaries in the sea. Hydrobiol 420:73-79

Kuklinski P, Berge J, McFadden L, Dmoch K, Zajaczkowski M, Nygård H, Piwosz K, Tatarek A (2013) Seasonality of occurrence and recruitment of Arctic marine benthic invertebrate larvae in relation to environmental variables. Polar Biol 36:549-560

Kulikova VA, Kolotukhina NK, Omelyanenko VA (2013) Pelagic larvae of the bivalves of Ussuriysky Bay, Sea of Japan. Russ J Mar Biol 39:440-444

Larsen JB, Frischer ME, Ockelmann KW, Rasmussen LJ, Hansen BW (2007) Temporal occurrence of planktotrophic bivalve larvae identified morphologically and by single step nested multiplex PCR. J Plankton Res 29:423-436

Layton KS, Martel AL, Hebert PDN (2014) Patterns of DNA barcode variation in Canadian Marine Molluscs. PLoS One. doi:10.1371/ journal.pone.0095003

Lebour MV (1938) Notes on the breeding of some lamellibranchs from Plymouth and their larvae. J Mar Biol Assoc UK 23:119-144

Linnaeus C (1758) Systema Naturae per regna tria naturae, secundum classes, ordines, genera, species, cum characteribus, differentiis, synonymis, locis. Editio decima, reformata. Laurentius Salvius: Holmiae vol 2, p 824

Linnaeus C (1767) Systema Naturae per regna tria naturae, secundum classes, ordines, genera, species, cum characteribus, differentiis, synonymis, locis. Editio duodecima, reformata. Laurentius Salvius, Holmiae, pp 533-1327

Liu J, Li Q, Kong L, Yu H, Zheng X (2011) Identifying the true oysters (Bivalvia: Ostreidae) with mitochondrial phylogeny and distance-based DNA. Mol Ecol Res 11:820-830
Loosanoff V, Miller W, Smith Davis CH, Chanley PE (1966) Dimensions and shapes of larvae of some marine bivalve mollusks. Malacologia 4:351-435

Lydeard C, Holznagel WE, Schnare MN, Gutell RR (2000) Phylogenetic analysis of molluscan mitochondrial LSU rDNA-sequences and secondary structures. Mol Phylogenet Evol 15:83-102

Meyer C, Paulay G (2005) DNA barcoding: error rates based on comprehensive sampling. PLoS Biol 3(12):e422

Mileikovsky S (1968) Distribution of pelagic larvae of bottom invertebrates of the Norwegian and Barents Seas. Mar Biol $1: 161-167$

Mohr N (1786) Forsøg til en islandsk naturhistorie, med adskillige oekonomiske samt andre anmærkninger. Trykt hos C.F. Holm, Copenhagen

Nilsen F, Cottier F, Skogseth R, Mattsson S (2008) Fjord-shelf exchanges controlled by ice and brine production: the interannual variation of Atlantic Water in Isfjorden, Svalbard. Cont Shelf Res 28:1838-1853

Norden-Andersen OG (1984) Meroplankton in Jørgen Brønlund Fjord, North Greenland. Medd Grønl 12:1-28

Ockelmann WK (1958) The zoology of East Greenland marine Lamellibranchiata. Bianco Lunos Bogtrykkeri A/S, Copenhagen

Ockelmann K (1962) Developmental types in marine bivalves and their distribution along the Atlantic coast of Europe. In: Cox LR, Peake JF (eds) Proceedings of the first European malacological congress. Conchological society of great Britain and Ireland and the malacological of London, London, pp 25-35

Oertzen JV (1972) Cycles and rates of reproduction of six Baltic Sea bivalves of different zoogeographical origin. Mar Biol 14:143-149

Palumbi S (1994) Genetic divergence, reproductive isolation, and marine speciation. Annu Rev Ecol Syst 25:547-572

Pawłowska J, Włodarska-Kowalczuk M, Zajączkowski M, Nygård H, Berge J (2011) Seasonal variability of meio- and macrobenthic standing stocks and diversity in an Arctic fjord (Adventfjorden, Spitsbergen). Polar Biol 34:833-845

Petersen GH (1978) Life cycles and population dynamics of marine benthic bivalves from the Disko Bugt area in West Greenland. Ophelia 17:95-120

Petersen GH (1999) Five recent Mya species, including three new species and their fossil connections. Polar Biol 22:322-328

Philippart CJ, Van Bleijswijk JD, Kromkamp JC, Zuur AF, Herman PM (2014) Reproductive phenology of coastal marine bivalves in a seasonal environment. J Plankton Res 36(6):1512-1527

Plazzi F, Passamonti M (2010) Towards a molecular phylogeny of Mollusks: bivalves' early evolution as revealed by mitochondrial genes. Mol Phylogenet Evol 57:641-657

Pulfrich A (1997) Seasonal variation in the occurrence of planktic bivalve larvae in the Schleswig-Holstein Wadden Sea. Helgoländer Meeresunters 51:23-39

Rees CB (1950) Continuous plankton records: first report on the distribution of lamellibranch larvae in the North Sea. Hull Bull Mar Ecol 3(20):105-134

Rozycki O (1992) Occurrence of gastropoda and Bivalvia in Hornsund Fiord (West Spitsbergen, Svalbard). Pol Polar Res $13: 41-52$

Rozycki O (1993) Shallow-water molluscs of Isfjorden (Western Spitsbergen). Pol Polar Res 14:55-63

RStudio (2012) RStudio: integrated development environment for $\mathrm{R}$ (Version 0.96.122) [Computer software]. Boston, MA. Retrieved May 20, 2012. Available from http://www.rstudio.org/

Savage N, Goldberg R (1976) Investigation of practical means of distinguishing Mya arenaria and Hiatella sp. larvae in plankton samples. Proc Natl Shellfish Assoc 66:42-53

Schlüter M, Rachor E (2001) Meroplankton distribution in the central Barents Sea in relation to local oceanographic patterns. Polar Biol 24:582-592 
Sewell MA, Lavery S, Baker CS (2006) Whose larva is that? molecular identification of planktonic larvae of the Ross Sea. New Zealand aquatic environment and biodiversity report no 3, Ministry of Wellington Fisheries, Wellington

Stanwell-Smith D, Peck LS, Clarke A, Murray A, Todd CD (1999) The distribution, abundance and seasonality of pelagic marine invertebrate larvae in the maritime Antarctic. Philos Trans R Soc B Biol Sci 354:471-484

Starr M, Himmelman JH, Therriault JC (1990) Direct coupling of marine invertebrate spawning with phytoplankton blooms. Science 247:1071-1074

Stübner EI, Soreide JE, Reigstad M, Marquardt M, BlachoviakSamolyk K (2016) Year-round meroplankton dynamics in highArctic Svalbard. J Plankt Res. doi:10.1093/plankt/fbv124

Sullivan CM (1948) Bivalve larvae of Malpeque Bay PEI. Bull Fish Res B Can 77:1-36

Tamura K, Stecher G, Peterson D, Filipski A, Kumar S (2013) MEGA6: molecular evolutionary genetics analysis version 6.0. Mol Biol Evol 30:2725-2729

Thatje S (2012) Effects of capability for dispersal on the evolution of diversity in Antarctic benthos. Integr Comp Biol 52:470-482

Thompson JD, Higgins DG, Gibson TJ (1994) CLUSTAL W: improving the sensitivity of progressive multiple sequence alignment through sequence weighting, position-specific gap penalties and weight matrix choice. Nucleic Acids Res 22:4673-4680

Thorson G (1936) The larval development, growth and metabolism of Arctic marine bottom invertebrates, compared with those of other seas. Medd Gronl 100:1-155

Thorson G (1946) Reproduction and larval development of Danish marine bottom invertebrates. Medd Komm Havundersog Kbh Ser Plankton 4:1-523

Thorson G (1950) Reproductive and larval ecology of marine bottom invertebrates. Biol Rev 25:1-45

Timofeev SF, Berchenko IV, Oleinik AA (2007) Pelagic larvae of bivalve mollusks and polychaetes in winter plankton of the Kara Sea. Russ J Mar Biol 33:193-195
Tranter DJ (1968) Zooplankton sampling, monographs on oceanographic methodology. UNESCO, Paris. doi:10.1038/211915a0

Vance R (1973) More on reproductive strategies in marine benthic invertebrates. Am Nat 107:339-352

Walker R, Heffernan P (1994) Temporal and spatial effects of tidal exposure on the gametogenic cycle of the northern quahog, Mercenaria mercenaria (Linnaeus, 1758) in coastal. J Shell Res 13:479-486

Webb KE, Barnes DKA, Clark MS, Bowden DA (2006) DNA barcoding: a molecular tool to identify Antarctic marine larvae. Deep-Sea Res 53:1053-1060

Weslawski JM, Zajackowski M, Kwasneiewski S, Jezierski J, Moskal W (1988) Seasonality in an Arctic fjord ecosystem: Hornsund, Spitsbergen. Polar Res 6:185-189

Weslawski JM, Kwasneiewski S, Wicktor J (1991) Winter in a Svalbard Fjord ecosystem. Arctic 44:115-123

Wlodarska-Kowalczuk M, Pearson TH (2004) Soft-bottom macrobenthic faunal associations and factors affecting species distributions in an Arctic glacial fjord (Kongsfjord, Spitsbergen). Polar Biol 27:155-167

Wlodarska-Kowalczuk M, Wesawski JM, Kotwicki L (1998) Spitsbergen glacial bays macrobenthos: a comparative study. Polar Biol 20:66-73

Wlodarska-Kowalczuk M, Szymelfenig M, Kotwicki L (1999) Macro- and meiobenthic fauna of the Yoldiabukta glacial bay (Isfjorden, Spitsbergen). Pol Polar Res 20:367-386

Wlodarska-Kowalczuk M, Szymelfenig M, Zajiczkowski M (2007) Dynamic sedimentary environments of an Arctic glacier-fed river estuary (Adventfjorden, Svalbard). II: meio-and macrobenthic fauna. Estuar Coast Shelf Sci 74:274-284

Zhang Z, Schwartz S, Wagner L, Miller W (2000) A greedy algorithm for aligning DNA sequences. J Comput Biol 7:203-214 